\title{
Assessment of the protective effect of green tea extract against ciprofloxacin-induced chondrotoxicity in albino rats (histochemical, and immunohistochemical study)
}

Ameera Kamal Khaleel ${ }^{1}$, Ramizu Bin Shaari ${ }^{1}$, Mohamad Arif Awang Nawi ${ }^{1}$, Ali Mihsen Al-Yassiri ${ }^{2}$

\author{
${ }^{1}$ School of Dental Sciences, Health Campus, Universiti Sains Malaysia, Kota Bharu, \\ Kelantan, Malaysia \\ ²Dentistry Department, Hilla University College, Babylon, Iraq
}

Submitted: 24 April 2021

Accepted: 20 June 2021

Arch Med Sci Civil Dis 2021; 6: e68-e74

DOI: https://doi.org/10.5114/amscd.2021.107845

Copyright (c) 2021 Termedia \& Banach

\section{Abstract}

Introduction: Ciprofloxacin is a broad-spectrum antibiotic which can cause a chondrotoxic effect in the growing condyle. Researchers found that green tea showed significant health benefits for a large number of disorders. The objective of the present research was to investigate the preventive potential of green tea extract against mandibular chondrotoxicity induced by ciprofloxacin in juvenile Wistar rats.

Material and methods: Twenty juvenile male rats were used and divided into four equal groups, the saline/water (S/W), saline/green tea $(\mathrm{S} / \mathrm{G})$, ciprofloxacin/water (C/W) and ciprofloxacin/green tea (C/G) treated groups. On day 32 of age, all the animals in C/W and C/G treated groups were subcutaneously injected with ciprofloxacin as two subcutaneous injections of $600 \mathrm{mg} / \mathrm{kg}$ of body weight, eight hours apart, while the S/W and S/G groups were subcutaneously injected with saline. The $S / G$ and $C / G$ groups were intragastrically gavaged by green tea extract in an oral dose of $300 \mathrm{mg} / \mathrm{kg} /$ day, 8 days before the subcutaneous injection of saline or ciprofloxacin. On day 34 , all the animals were anaesthetized, and the mandibular condyle samples were taken immediately and processed.

Results: In comparison with the C/W treated group, the C/G treated group showed a significant increase in the thickness of the mandibular condylar cartilage, cartilage cell number, glycosaminoglycan content, and $\mathrm{Bcl}-2 \mathrm{im}$ mune expression $(p<0.05)$.

Conclusions: This study provides the first evidence that green tea extract can significantly decrease the chondrotoxic effects of ciprofloxacin in a rat mandibular condyle cartilage model.

Key words: antibiotics, mandibular condylar cartilage, Bcl-2, safranin O.

\section{Introduction}

Ciprofloxacin (CIP) hydrochloride is a yellow substance which consists of 1-cyclopropyl-6-fluoro-1,4-dihydro-4-oxo-7-1-piperazinyl-3-quinolinecarboxylic acid with a molecular weight of 331.4 and a formula of $\mathrm{C} 17 \mathrm{H}$ 18 FN3O3 [1]. The susceptibility of multi-resistant pathogens to CIP, greater bioavailability and tissue penetration, and higher plasma concentrations were the reasons for its use [2, 3]. It is indicated for the treatment of joint infections [4], gastrointestinal infections [5], anthrax [6], respira-

\author{
Corresponding author: \\ Ramizu Bin Shaari \\ School of Dental \\ Sciences \\ Health Campus \\ Universiti Sains Malaysia \\ Kubang Kerian \\ 16150 Kota Bharu \\ Kelantan, Malaysia \\ E-mail: ramizu@usm.my
}


tory infections [7], and urinary infection [8]. It can interrupt the DNA replication in bacterial cells and prevent cell division [9].

Previously reported cases indicated that CIP can induce chondrotoxicity and tendinopathy [10] It must not be used as a first line agent in children due to its risk of injury to the joints [11]. It causes necrosis of the chondrocytes, matrix degeneration and cleft formation in the center of articular cartilage [12]. Supplementation with magnesium [13], calcium [14], zinc [15] or vitamin E [16] can diminish the induced chondrotoxicity by preventing DNA oxidation and oxidative stress and inhibiting overexpression of COX-2, which is a key enzyme in chondrocyte apoptosis.

Chondrocytes are specialized cells which synthesize extracellular matrix for condylar cartilage. Several studies have found that $\mathrm{Bcl}-2$ plays a role in controlling apoptosis of cartilage cells [17-19]. Bcl-2 can be activated by proinflammatory cytokines, and its overexpression can suppress apoptosis as a response to different stimuli $[20,21]$.

(-)-Epicatechin (EC), (-)-epigallocatechin (EGC), (-)-epicatechin gallate (ECG), and (-)-epigallocatechin gallate (EGCG) are polyphenolic flavonoids found in green tea (GT). The most active component of GT is EGCG [22]. The other constituents present in GT are: minerals (e.g. magnesium, calcium and zinc), vitamins (e.g. vitamin E), proteins, amino acids, carbohydrates and others [23]. GT has shown significant health benefits for various disorders [24]. Previous research has revealed the importance of dietary sources. Dietary therapy, if effective, might be a safer method for the prevention of the chondrotoxic effect of CIP. The prevention of chondrotoxicity by GT extract (GTE) can facilitate the use of CIP in children and during pregnancy and lactation periods.

The objective of the present research was to study the preventive potential of GTE in the mandibular chondrotoxicity induced by CIP in juvenile Wistar albino rats.

\section{Material and methods}

The total number of animals used in the study was 20 male Wister Albino rats. They were aged 24 days, weighing 35-45 g. All rats were kept in standard conditions, and maintained on a 12hour light and dark cycle, at $25 \pm 6^{\circ} \mathrm{C}$, fed with standard rat chow, and allowed to drink water ad libitum. The research project was approved by the USM Institutional Animal Care and Use Committee (USM IACUC).

\section{Experimental design}

The 20 male rats were divided into four equal groups (Table I). All rats of the $\mathrm{C} / \mathrm{W}$ and $\mathrm{C} / \mathrm{G}$ groups were administered CIP hydrochloride (Bactiflox, Switzerland, $750 \mathrm{mg}$ ) as two subcutaneous injections of $600 \mathrm{mg} / \mathrm{kg}$ of body weight, $8 \mathrm{~h}$ apart [16]. The GTE was prepared by adding $2.5 \mathrm{~g}$ of green tea (Alwazah, Sri Lanka) to $50 \mathrm{ml}$ of boiling water in a porcelain tea pot and steeped for $20 \mathrm{~min}$. The extract was cooled to room temperature then filtered. The GTE was prepared daily to prevent degradation of important constituents [25] and used in an oral dose of $300 \mathrm{mg} / \mathrm{kg} /$ day $[26,27]$.

\section{Rats' anesthesia, dissection, tissue processing, and staining}

Rats were first anaesthetized with intramuscular injection of xylazine and ketamine. After separation of the mandible, the right and left condylar heads were collected, fixed in $4 \%$ neutral buffered formalin with $\mathrm{pH} 7.4$ for 1 day at $4^{\circ} \mathrm{C}$, and then decalcified with $10 \%$ ethylene diamine tetra acetic acid containing dimethyl sulfoxide $(\mathrm{pH}$ 7.2) for 2 weeks, processed, sectioned and stained.

\section{Hematoxylin and eosin stain (H\&E)}

Two sagittal sections per animal were stained with H\&E. The histomorphometric measurements were made in a blinded and nonbiased manner using an objective micrometer (EW10X/20/Japan).

Table I. Experimental design of the study

\begin{tabular}{|lc|}
\hline Group & Description \\
\hline $\begin{array}{l}\text { Group } 1 \\
(\mathrm{~S} / \mathrm{W})\end{array}$ & $\begin{array}{c}\text { On day } 32 \text { of age, all the animals in this group were subcutaneously injected with physiological saline } \\
(0.9 \% \mathrm{NaCl}) \text { in the same manner as CIP, and treated by intragastric gavage of distilled water } 8 \text { days } \\
\text { before the subcutaneous injection of physiological saline and continued for 10 days (day 24 to day 34) }\end{array}$ \\
\hline $\begin{array}{l}\text { Group } 2 \\
(\mathrm{~S} / \mathrm{G})\end{array}$ & $\begin{array}{r}\text { On day } 32 \text { of age, all the animals in this group were subcutaneously injected with physiological saline } \\
(0.9 \% \mathrm{NaCl}) \text { in the same manner as CIP, and treated by intragastric gavage of GTE } 8 \text { days before the } \\
\text { subcutaneous injection of physiological saline and continued for 10 days (day 24 to day 34) }\end{array}$ \\
\hline $\begin{array}{l}\text { Group } 3 \\
\text { (C/W) }\end{array}$ & $\begin{array}{c}\text { On day 32 of age, all the animals in this group were subcutaneously injected with CIP, and treated by } \\
\text { intragastric gavage of distilled water 8 days before the subcutaneous injection of CIP and continued for } \\
\text { 10 days (day 24 to day 34) }\end{array}$ \\
\hline $\begin{array}{l}\text { Group 4 } \\
\text { (C/G) }\end{array}$ & $\begin{array}{c}\text { On day 32 of age, all the animals in this group were subcutaneously injected with CIP, and treated by } \\
\text { intragastric gavage of GTE } 8 \text { days before the subcutaneous injection of CIP and continued for ten days } \\
\text { (day 24 to day 34) }\end{array}$ \\
\hline
\end{tabular}


The total thickness of the MCC was measured, which is represented by the distance from the external articular surface to the external boundary of the subchondral bone. Three different measurements for the MCC thickness were made, one in the middle of the thickest portion of the middle third, and one $200 \mu \mathrm{m}$ anterior and one $200 \mu \mathrm{m}$ posterior to this line. The number of cartilage cells was measured by counting the cells that intersected these three lines [28]. The result of three measurements per section of condyle $100 \times$ magnification resulted in a total of 6 measurements per animal, and the mean value was then calculated.

\section{Safranin O stain}

The safranin O uptake is a measure of the glycosaminoglycans loss and distribution. The pathologic condition in MCC was assessed using the modified system of Mankin scoring [29, 30]. Background staining intensity of the pericellular matrix: normal staining $=0$, slight reduction $=1$, severe reduction $=2$. Staining intensity of the territorial and interterritorial matrix: normal staining $=0$, slight reduction $=1$, moderate reduction $=2$, severe reduction or no stain $=3$. Spatial arrangement of cartilage cells: normal $=0$, cluster $=1$, hypocellularity $=2$. Structure of cartilage: normal and smooth noneroded cartilage surface $=0$, irregular surface $=1$, vacuoles $=2$, blister, cleft, erosion, or separation of calcified from uncalcified cartilage $=3$. The maximum score for the degenerative articular cartilage is 10 .

\section{Immunohistochemistry for Bcl-2}

Sections were deparaffinized by two changes of xylene 10 min each, hydrated in a series of alcohols $(100 \%, 70 \%, 50 \%)$ and then distilled water, three minutes each. Tris-EDTA was used as antigen retrieval solution. Sections were retrieved in Thermo Scientific for 15 min using the PathnSitu Multi-Epitope Retrieval System, allowed to cool, washed in distilled water and then in PBS for 3 min, two changes each, blocked for 10 min with PolyExcel $\mathrm{H}_{2} \mathrm{O}_{2}$, and washed in PBS. Tissue sections were then incubated with primary antibody for 45 min (PathnSitu PolyExcel Detection System, ready to use, London, a monoclonal rabbit oncoprotein, Isotope Rabbit IgG, Clone EP36, and dilution 1 : 50), washed in PBS, incubated with the PolyExcel Target Binder for 10 min, washed in PBS, followed by a PolyExcelPoly HRP labeled polymer for 10 min of incubation at room temperature, and washed in PBS. The staining procedure was completed by incubation with 3,3'-diaminobenzidine (PolyExcel Stunn DAB) substrate-chromogen for 5 min, which results in a brown color at the antigen site [31]. Tissue sections were then covered with
Mayer's hematoxylin solution for $30 \mathrm{~s}$ as a nuclear counterstain, dehydrated through graded alcohol, cleared and then coverslipped.

With each batch of stain, a negative control tissue specimen was used. In the middle third of the MCC, which is the thickest portion, the total numbers of immune-positive and immune-negative cells were counted. The positive cells were expressed as the percentage of the total cells in a high-power field $400 x$ in five randomly selected areas per section. The terminal hypertrophic chondrocyte was not quantified because of the extremely low degree of its immunoreactivity [32]

\section{Statistical analysis}

Results are given as mean \pm standard deviation. Using the ANOVA test, the potential differences among groups were evaluated. Statistical calculations were done using SPSS computer program (Statistical Package for the Social Science; SPSS Inc., version 24). The non-parametric Kruskal-Wallis test was used to analyze the significant differences in histochemical and immunohistochemical data. A $p$-value less than or equal to 0.05 was considered statistically significant.

\section{Results}

\section{Histochemical results}

Histological structures of the MCC in the S/W and S/G groups were compose of different layers which can be obviously distinguished (Figure 1 ). In comparison with the $C / G$ group, all cases of the C/W group were associated with a decrease in the thickness of the MCC, irregularly distributed chondrocytes causing difficulty in differentiating the different cartilaginous layers, and severe reduction in the safranin O stain (Figure 2). Two cases of the C/W group were associated with a cleft in the intermediate zone of the cartilage.

A nonsignificant difference was found between the S/W and S/G groups regarding the MCC thickness, cell numbers, and safranin $O$ stain uptake $(p>0.05)$. The C/W group showed a significant decrease in MCC thickness and cell numbers, with a severe reduction in the safranin $\mathrm{O}$ stain in comparison with the other three groups $(p<0.05)$, as seen in Table II.

\section{Immunohistochemical results}

In the $S / W, S / G$, and $C / G$ groups, the $\mathrm{Bcl}-2$ immunoreactivity displayed marked cytoplasmic immune activity of Bcl-2 (Figure 3). Statistical analysis did not show a significant difference between the S/W and S/G groups regarding the percentages of $\mathrm{Bcl}-2$ positive cells $(p>0.05)$, but a significant decrease was seen in the C/W and 

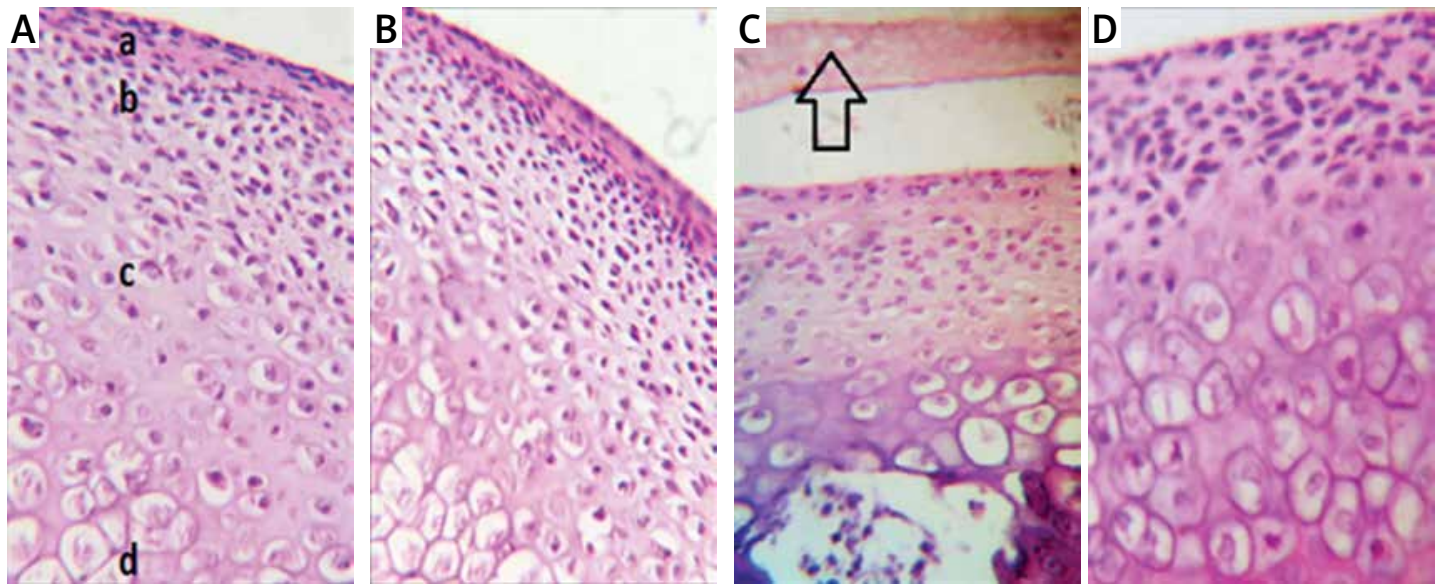

Figure 1. Photomicrograph of the rat's mandibular condylar cartilage section in the S/W (A) and S/G (B) groups showing the different cell layers: $a$ - articular; $b$ - proliferative; $c$ - mature; and d - hypertrophic cell layers. $\mathrm{C}$ - Photomicrograph of a section in the middle third of the rat's mandibular condyle cartilage near the thinnest area of the condylar disc (arrow) in the C/W group shows decreased thickness and irregularity of cellular arrangement. D - The C/G group shows greater thickness in comparison with the C/W group (H\&E 400x)
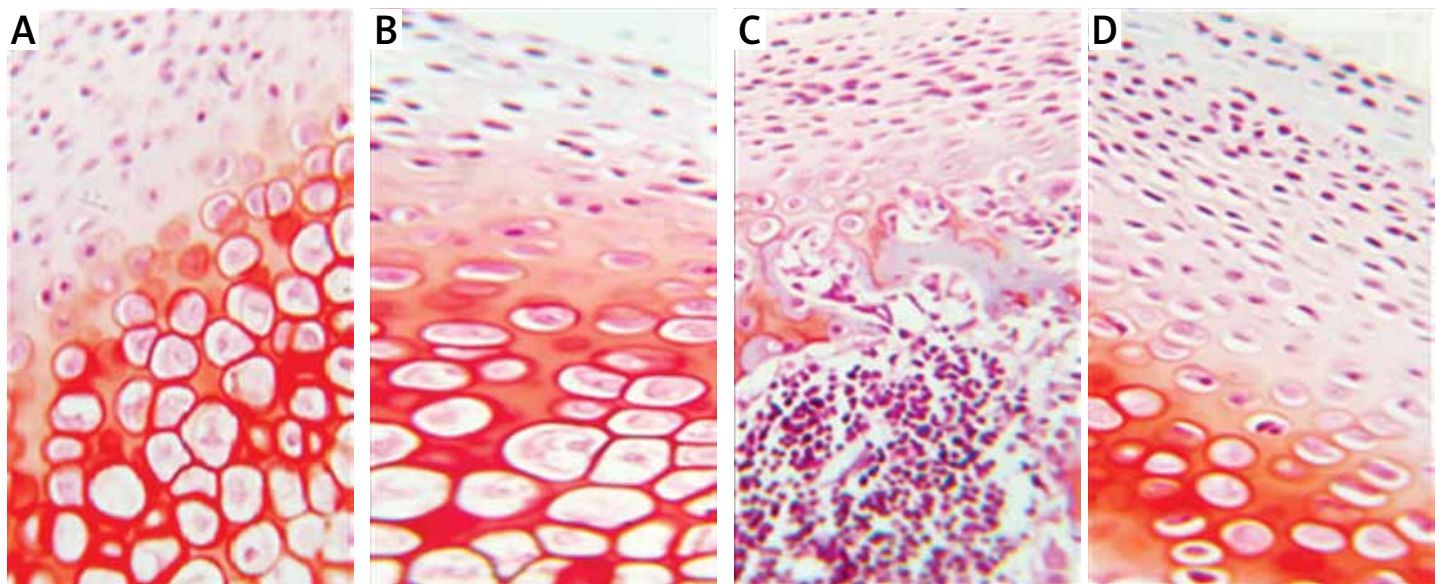

Figure 2. Photomicrographs of sections of rat's mandibular condylar cartilages. In the S/W (A) and S/G (B) groups, the safranin $\mathrm{O}$ staining of the intercellular matrix appears normal. C - The C/W group shows a severe reduction in the staining. D - A moderate reduction is seen in the mandibular condylar cartilage of the C/G group (safranin O 400x)

$\mathrm{C} / \mathrm{G}$ groups in relation with them. The $\mathrm{C} / \mathrm{G}$ group showed significantly higher $\mathrm{Bcl}-2$ immuno-expression in comparison with the C/W group $(p<0.05)$, as seen in Table II.

\section{Discussion}

The present study showed that the MCC layer mean thickness and number of cartilage cells in the S/W group were $373 \pm 0.160 \mu \mathrm{m}$ and 20.8 \pm 2.039 , respectively. Oksayan et al. [33] found that the anterior and posterior total thickness of MCC were $342.198 \pm 241.77$ and $314.69 \pm 194.15$ $\mu \mathrm{m}$, respectively. Cavalli et al. [34] found that the mean number of cartilage cells in MCC in 60-day old adult rats was $416.4 \pm 79.9$. The differences in the results may be due to the method used for measurement. Glycosaminoglycans are polysaccharides that can play an important role in determining the biomechanical properties of the MCC [35]. In the
S/W group, the Mankin score for glycosaminoglycan distribution was $0.4 \pm 0.489$. This result is in agreement with that of the study by Yuan et al. [36].

Statistical analysis showed no significant difference between the S/W and the S/G groups regarding the MCC layer mean thickness, number of cartilage cells, and glycosaminoglycan score. The Huang et al. [37] study also found a non-toxic effect of catechins in chondrocyte proliferation and later on condylar cartilage matrix components.

The present study showed that the MCC layer mean thickness, cell number, and the glycosaminoglycan score in the C/W group were significantly lower than in the other groups. In addition, the study revealed two cases with cleft formation within the intermediate zone. Yabe et al. [38] found that vesicles were observed on the articular surfaces of all juvenile dogs after two doses of ofloxacin. Halawa's [10] study also found that the 
Table II. Histochemical and immunohistochemical analysis for rats' mandibular condylar cartilage in different groups of the study

\begin{tabular}{|c|c|c|c|c|c|c|c|c|}
\hline Group & $\begin{array}{c}\text { Thickness } \\
{[\mu \mathrm{m}]}\end{array}$ & $P$-value & $\begin{array}{c}\text { Number of } \\
\text { cartilage cells }\end{array}$ & $P$-value & $\begin{array}{l}\text { Mankin } \\
\text { score }\end{array}$ & $P$-value & Bcl-2\% & $P$-value \\
\hline S/W & $373 \pm 0.160$ & 0.143 & $20.8 \pm 2.039$ & 0.094 & $0.4 \pm 0.489$ & 0.601 & $74.166 \pm 5.367$ & 0.3366 \\
\hline$S / G$ & $356 \pm 10.198$ & & $18.4 \pm 1.496$ & & $0.6 \pm 0.489$ & & $71.5 \pm 2.432$ & \\
\hline S/W & $373 \pm 0.160$ & $0.009^{*}$ & $20.8 \pm 2.039$ & $0.009^{*}$ & $0.4 \pm 0.489$ & $0.006^{*}$ & $74.166 \pm 5.367$ & $0.0039 *$ \\
\hline $\mathrm{C} / \mathrm{W}$ & $162 \pm 7.483$ & & $10.4 \pm 2.059$ & & $6.166 \pm 1.067$ & & $8.166 \pm 2.544$ & \\
\hline S/W & $373 \pm 0.160$ & $0.009^{*}$ & $20.8 \pm 2.039$ & $0.009^{\star}$ & $0.4 \pm 0.489$ & $0.016^{*}$ & $74.166 \pm 5.367$ & $0.0039^{*}$ \\
\hline$C / G$ & $210 \pm 14.142$ & & $15.8 \pm 1.166$ & & $2.2 \pm 0.748$ & & $45.333 \pm 5.185$ & \\
\hline$S / G$ & $356 \pm 10.198$ & $0.009^{*}$ & $18.4 \pm 1.496$ & $0.009^{*}$ & $0.6 \pm 0.489$ & $0.006^{\star}$ & $71.5 \pm 2.432 \%$ & $0.0039^{*}$ \\
\hline $\mathrm{C} / \mathrm{W}$ & $162 \pm 7.483$ & & $10.4 \pm 2.059$ & & $6.166 \pm 1.067$ & & $8.166 \pm 2.544$ & \\
\hline$S / G$ & $356 \pm 10.198$ & $0.009^{*}$ & $18.4 \pm 1.496$ & $0.028^{*}$ & $0.6 \pm 0.489$ & $0.021^{\star}$ & $71.5 \pm 2.432 \%$ & $0.0039^{*}$ \\
\hline$C / G$ & $210 \pm 14.142$ & & $15.8 \pm 1.166$ & & $2.2 \pm 0.748$ & & $45.333 \pm 5.185$ & \\
\hline $\mathrm{C} / \mathrm{W}$ & $162 \pm 7.483$ & $0.009^{*}$ & $10.4 \pm 2.059$ & $0.012^{*}$ & $6.166 \pm 1.067$ & $0.006^{*}$ & $8.166 \pm 2.544$ & $0.0039^{*}$ \\
\hline$C / G$ & $210 \pm 14.142$ & & $15.8 \pm 1.166$ & & $2.2 \pm 0.748$ & & $45.333 \pm 5.185$ & \\
\hline
\end{tabular}

*Significant $p<0.05$.
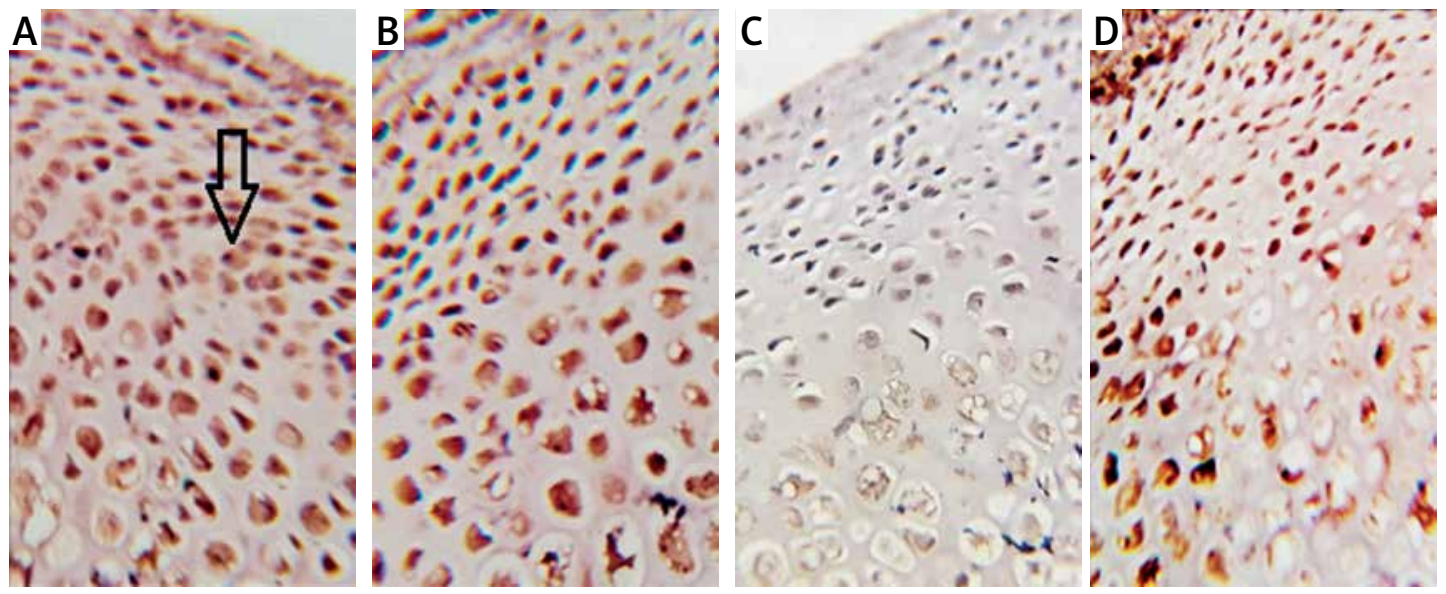

Figure 3. Photomicrographs of sections of rat's mandibular condylar cartilages, immune stained with Bcl-2, in S/W (A), S/G (B), C/W (C) and C/G (D) groups. The positive cells show brown staining in the cytoplasm, arrow (immunohistochemistry 400x)

CIP treated animals showed a significant decrease in the condylar cartilage thickness, the number of chondrocytes, and the glycosaminoglycan content of the femoral articular matrix with areas of decreased staining affinity. The articular cartilage damage in young animals can be caused by DNA oxidative damage of the condylar cartilage chondrocytes and collagen with loss of the integrity of extracellular proteins [39]. The formation of CIP-chelate complexes can induce a deficiency of the functionally available $\mathrm{Mg}$, which resulted in articular cartilage damage [40].

The present study showed that the MCC layer mean thickness, number of cells, and the glycosaminoglycan score in the $\mathrm{C} / \mathrm{G}$ group were significantly higher than in the C/W group. The GT polyphenols can increase levels of serum glutathione peroxidase, reduce serum malondialdehyde, increase the anti-oxidation ability and decrease the damage to tissues [41]. In human articular chondrocytes, EGCG can also enhance aggrecan core protein synthesis [42]. Aggrecan is a large ag- gregating proteoglycan and its degradation can be inhibited by consumption of GTE or EGCG, which can selectively inhibit the activities of aggrecanases [43]. It was also found that the production of MMP-1 and MMP-13 was inhibited in human chondrocytes which were pre-treated with EGCG [44]. The GT polyphenols can also inhibit the gelatinolytic activity of MMP-2 [45].

Guay's study [46] revealed that multivalent cations such as $\mathrm{Mg}, \mathrm{Ca}, \mathrm{Zn}$ and other minerals can interact with fluoroquinolone and substantially reduce its bioavailability, leading to subtherapeutic drug concentrations at the infection site. Minerals present in GT may be responsible for this action. GT also contains various vitamins such as vitamins $E$ and $C$ which are associated with different activities including antioxidant, anti-apoptosis [47, 48], and radical scavenging antioxidant activity [49]. It was found that $100 \mathrm{IM}$ of vitamin $\mathrm{E}$ or $10 \mathrm{mM}$ of ascorbic acid can inhibit the generation of CIP-induced hydrogen peroxide and significantly inhibit CIP cytotoxicity due to the possible antagonistic 
properties of vitamins $\mathrm{E}$ and $\mathrm{C}$ when they are used with CIP [50]. These constituents of GTE may have anti-chondrotoxic effects against CIP activity.

In the present study, a significant decrease in Bcl-2 immuno-expression as an antiapoptotic marker in MCC of C/W group was observed. Condylar cartilage damage in growing animals was mainly due to DNA oxidative damage of the chondrocytes [51], deficiency of functionally available $\mathrm{Mg}$ [52], inhibition of mitochondrial dehydrogenase [53], and altered metabolism of DNA [54]. The beneficial effect of GTE by the significant increase in the $\mathrm{Bcl}-2$ immune expression in the $\mathrm{C} / \mathrm{G}$ group in comparison with the $\mathrm{C} / \mathrm{W}$ group can be attributed to the high content of catechins. Studies by Schroeder et al. [55] and Cong et al. [56] revealed that GT can restore the function of $\mathrm{BCl}-2$. In contrast to these studies, Singh et al. [57] reported that EGCG could effectively lower pro-apoptotic gene activities with no effect on the anti-apoptotic genes. The differences in the results may be due to the different types and concentrations of catechins or GTE used in these studies. In conclusion, this study provides the first evidence that GT extract can significantly decrease the chondrotoxic effects of CIP in a rat model by increasing the MCC thickness, cartilage cell number, glycosaminoglycan distribution, and $\mathrm{Bcl}-2$ immune expression.

\section{Conflict of interest}

The authors declare no conflict of interest.

\section{References}

1. Tamma PD, Cosgrove SE, Maragakis LL. Combination therapy for treatment of infections with Gram-negative bacteria. Clin Microbiol Rev 2012; 25: 450-70.

2. Sharma RC, Jain A, Jain S, et al. Ciprofloxacin: review on developments in synthetic, analytical, and medicinal aspects. J Enzyme Inhib Med Chem 2010; 25: 577-89.

3. Rodriguez CA, Agudelo M, Zuluaga AF, et al. Impact on resistance of the use of therapeutically equivalent generics: the case of ciprofloxacin. Antimicrob Agents Chemother 2015; 59: 53-8.

4. Suh B, Lorber B. Quinolones. Med Clin North Am 1995; 79: 869-94

5. Hamer DH, Gorbach SL. Use of the quinolones for the treatment and prophylaxis of bacterial gastrointestinal infections, in the quinolones, (edit., Andriole, V.T.), Academic Press, New York 1998; 267-85.

6. Oliphant CM, Green GM. Quinolones: a comprehensive review. Am Fam Physician 2002; 65: 455-64.

7. Yu VL, Vergis E. New macrolides or new quinolones as monotherapy for patients with community acquired pneumonia. Chest 1998; 113: 1158-9.

8. Prajapati BS, Prajapati RB, Patel BS. Advances in management of urinary tract infections. Indian J Pediatr 2008; 75: 809-12.

9. Fief CA, Hoang KG, Phipps SD, et al. Examining the impact of antimicrobial fluoroquinolones on human DNA topoisomerase Il $\alpha$ and li $\beta$. ACS Omega 2019; 4: 4049-55.
10. Halawa AM. Effects of ciprofloxacin on the articular cartilage and epiphyseal growth plate cartilage in the growing albino rats and the possible protective role of vitamin E (alpha-Tocopherole): a histological and morphometric study. Egypt J Histol 2010; 33: 1-5.

11. Sendzik J, Shakibaei M, Schafer-Korting M, et al. Fluoroquinolones cause changes in extracellular matrix, signaling proteins, metalloproteinases and caspase- 3 in cultured human tendon cells. Toxicology 2005; 212: 24-36.

12. Kato M. Chondrotoxicity of quinolone antimicrobial agent. J Toxicol Pathol 2008; 21: 123-31.

13. Stahlmann R, Schwabe R, Pfister K, et al. Supplementation with magnesium and tocopherol diminishes quinolone-induced chondrotoxicity in immature rats. Drugs 1999; 58 (Suppl. 2): 393-4.

14. Kang SJ, Kim JW, Kim KY, et al. Protective effects of calcium gluconate on meniscectomy in Sprague-Dawley rats. J Orthop Surg Res 2014; 9: 14.

15. Channa MA. Pre and post-natal effects of ciprofloxacin on growing cartilage prevented by zinc chloride in Wister albino rats. PhD Thesis, 2014; Baqai Medical University, Karachi, Pakistan.

16. Pfister K, Mazur D, Vormann J, et al. Diminished ciprofloxacin-induced chondrotoxicity by supplementation with magnesium and vitamin $E$ in immature rats. Antimicrob Agents Chemother 2007; 51: 1022-7.

17. Reed JC. Mechanisms of apoptosis. Am J Pathol 2000; 157: $1415-30$

18. Muir H. The chondrocyte, architect of cartilage. Biomechanics, structure, function and molecular biology of cartilage matrix macromolecules. Bioessays 1995; 17: 1039-48.

19. Lee DA, Bentley G, Archer CW. The control of cell division in articular chondrocytes. Osteoarthritis Cartilage 1993; 1: 137-46.

20. Amling M, Neff L, Tanaka S, et al. Bcl-2 lies downstream of parathyroid hormone-related peptide in a signaling pathway that regulates chondrocyte maturation during skeletal development. J Cell Biol 1997; 136: 205-13.

21. Mandal M, Maggirwar SB, Sharma N, et al. Bcl-2 prevents CD95 (Fas/APO-1)-induced degradation of lamin B and poly (ADP-ribose) polymerase restores the NF-kappaB signaling pathway. J Biol Chem 1996; 271: 30354-9.

22. Reto M, Figueira ME, Mota-Filipe H, Almeida CMM. Chemical composition of green tea (Camellia sinensis), infusions commercialized in Portugal. Plant Foods $\mathrm{Hu}$ man Nutrition 2008; 62: 139-44.

23. Musial C, Kuban-Jankowska A, Gorska-Ponikowska M. Beneficial properties of green tea catechins. Int J Mol Sci 2020; 21: 1744.

24. Khaleel AK, Bin Shaari R, Awang Nawi MA, et al. Health benefits of green tea and green tea catechins with an overview on their anti-cancer activity. Int J Pharm Res 2020; 12: 1703-11.

25. Rahman AF, Purwanto DA, Isnaeni A. The effect of vitamin C addition on epigallocatechin gallate (EGCG) stability in green tea solution. J Farmasi Dan Ilmu Kefarmasian Indonesia 2019; 6: 62-8.

26. Arteel GE, Uesugi T, Bevan LN, et al. Green tea extract protects against early alcohol induced liver injury in rats. Biol Chem 2002; 383: 663-7.

27. Abdel-Raheem IT, El-Sherbiny GA, Taye A. Green tea ameliorates renal oxidative damage induced by gentamicin in rats. Pak J Pharm Sci 2010; 23: 21-8.

28. Orajavi M, Laaksonen S, Haura R, et al. Changes in type I and type II collagen expression in rat mandibular condylar cartilage associated with aging and dietary loading. J Oral Facial Pain Headache 2018; 32: 258-65. 
29. Xu L, Servais J, Polur I, et al. Attenuation of osteoarthritis progression by reduction of the discoidin domain receptor 2 in mice. Arthritis Rheum 2010; 62: 2736-44.

30. Maślanka T, Jaroszewski JJ, Mikołajczyk A, et al. Effect of increasing doses of enrofloxacin on chicken articular cartilage. Pol J Vet Sci 2009; 12: 21-33.

31. Boenish T. Hand book of Immunohistochemical Staining Methods. $3^{\text {rd }}$ ed. Carpinteria, Dako North America 2001; 26-31.

32. Mocetti P, Silvestrini G, Ballanti P, et al. Bcl-2 and Bax expression in cartilage and bone cells after high-dose corticosterone treatment in rats. Tissue Cell 2001; 33: 1-7.

33. Oksayan R, Sökücü $O$, Üçüncü N. Histomorphometric evaluation of the effects of mandibular advancement appliance and low-level laser therapy (LLLT) with different doses on condylar cartilage and subchondral bone in rats. Int J Morphol 2010; 38: 252-8.

34. Cavalli MA, Goncalves A, Pereira JNB, et al. Evaluation of protein under nourishment on the condylar process of the Wistar rat mandible correlation with insulin receptor expression. J Appl Oral Sci 2015; 23: 135-44.

35. Neves MI, Araújo M, Moroni l, et al. Glycosaminogly can-inspired biomaterials for the development of bioac tive hydrogel networks. Molecules 2020; 25: 978.

36. Yuan J, Ding W, Wu N, et al. Protective effect of genistein on condylar cartilage through downregulating NF- $\mathrm{KB}$ expression in experimentally created osteoarthritis rats. Bio Med Res Int 2019; 2019: 2629791.

37. Huang $H$, Liu Q, Liu L, et al. Effect of pigallocatechin-3-gallate on proliferation and phenotype maintenance in rabbit articular chondrocytes in vitro. Exper Ther Med 2015; 9: 213-8.

38. Yabe K, Satoh H, Ishii Y, et al. Early pathophysiologic feature of arthropathy in juvenile dogs induced by ofloxacin, a quinolone antimicrobial agent. Vet Pathol 2004; 41: 673-81.

39. Mao X, Gu C, Chen D, et al. Oxidative stress-induced diseases and tea poly-phenols. Oncotarget 2017; 8: 81649-61.

40. Stahlmann R, Forster C, Shakibaei M, et al. Magnesium deficiency induces joint cartilage lesions in juvenile rats which are identical to quinolone-induced arthropathy. Antimicrob Agents Chemother 1995; 39: 2013-8.

41. Ahmed NA, Radwan NM, Aboul Ezz HS, et al. The antioxidant effect of green tea mega EGCG against electromagnetic radiation-induced oxidative stress in the hippocampus and striatum of rats. Electromagn Biol Med 2017; 36: 63-73.

42. Andriamanalijaona R, Kypriotou M, Baugé C, et al. Comparative effects of 2 antioxidants, selenomethionine and epigallocatechin-gallate, on catabolic and anabolic gene expression of chondrocytes. J Rheumatol 2005; 32: 1958-67.

43. Ikbal A, Roy S. Health benefits of green tea: a mini review. J Entomol Zool Studies 2020; 8: 1424-30.

44. Ahmed SA, Wang N, Lalonde M, et al. Green tea polyphenol epigallocatechin-3gallate (EGCG) differentially inhibits interleukin-1beta induced expression of matrix metalloproteinase 1 and-13 in human chondrocytes. J Pharmacol Exp Ther 2004; 308: 767-73.

45. Cheng X, Kuzuya M, Kanda S, et al. Epigallocatechin-3-gallate binding to MMP-2 inhibits gelatinolytic activity without influencing the attachment to extracellular matrix proteins but enhances MMP-binding to TIMP-2. Arch Biochem Biophys 2003; 415: 126-32.

46. Guay D. Drug Interactions in Infectious Diseases 2011; 277-332.
47. Basu A, Betts NM, Mulugeta A, et al. Green tea supplementation increases glutathione and antioxidant capacity in adults with the metabolic syndrome. Nutr Res 2013; 33: 180-7.

48. Heikal TM, Ghanem HZ, Soliman MS. Protective effect of green tea extracts against dimethoate induced DNA damage and oxidant/antioxidant status in male rats. Biohealth Sci Bulletin 2011; 3: 1-11.

49. Pouzaud F, Bernard-Beaubois K, Thevenin $M$, et al. In vitro discrimination of fluoroquinolones toxicity on tendon cells: involvement of oxidative stress. J Pharmacol Exp Ther 2004; 308: 394-402.

50. Masadeh MM, Mhaidat NM, Alzoubi KH. Ciprofloxacin-induced antibacterial activity is reversed by vitamin E and vitamin C. Curr Microbiol 2012; 64: 457-62.

51. Maślanka T, Jaroszewski JJ, Chrostowska M, et al. Pathogenesis of quinolone-induced arthropathy: a review of hypotheses. Pol J Vet Sci 2004; 7: 323-31.

52. Stahlmann R, Forster C, Shakibaei M, et al. Magnesium deficiency induces joint cartilage lesions in juvenile rats which are identical to quinolone-induced arthropathy. Antimicrob Agents Chemother 1995; 39: 2013-8.

53. Hildebrand HG, Kempka G, Schluter A, et al. Chondrotoxicity of quinolones in vivo and in vitro. Arch Toxicol 1993; 67: 411-5.

54. Rusquet R, Bonhommet M, David JC. Quinolone antibiotics inhibit eucaryotic DNA polymerase alpha and beta, terminal deoxynucleotidyl transferase but not DNA ligase. Biochem Biophys Res Commun 1984; 121: 762-9.

55. Schroeder EK, Kelsey NA, Doyle J, et al. Green tea epigallocatechin 3-gallate accumulates in mitochondria and displays a selective antiapoptotic effect against inducers of mitochondrial oxidative stress in neurons. Antioxid Redox Signal 2009; 11: 469-80.

56. Cong L, Cao C, Cheng Y, et al. Green tea polyphenols attenuated glutamate excitotoxicity via antioxidative and antiapoptotic pathway in the primary cultured cortical neurons. Oxid Med Cell Longev 2016; 2016: 2050435.

57. Singh NA, Mandal AKA, Khan ZA. Potential neuroprotective properties of epigallocatechin-3-gallate (EGCG). Nutr J 2016; 15: 60. 